DOI:

\title{
Comparison between Systematical Budget Allocation Modeling Selection Methods in Low-Income Residential Rehabilitation Projects
}

\author{
Ahmed Nouh Meshref ${ }^{1 *}$, M. A. Elsisy ${ }^{2}$ \\ ${ }^{1}$ Civil Engineering Department, ${ }^{2}$ Basic Engineering Sciences Department, Faculty of \\ Engineering, Benha University, Egypt. \\ *Corresponding author : Dr.ahmednouh@bhit.bu.edu.eg
}

\begin{abstract}
One of the most important problems for governments and private sectors on construction industry is how to allocate budgets for public residential projects. Low-income residential projects in developing countries have major effects on implementing the principles of sustainable development. Limited budgets in concrete rehabilitation structures represent challenges for the decision-makers. The budget allocation methods proposed in this paper can be easily meet the actual changing demands of response budget policies. This paper proposed a comprehensive comparison between the Topsis method and Simo's ranking method in lowincome residential rehabilitation projects. Also, the assignment problem presented to select a suitable project depending on the different clusters. This proposed comparative study aims the decision-maker (DM) to select the optimum method. Finally 13 criteria have been gathered from comprehensive literature. The gathered criteria have been reviewed through unstructured interviews with engineers work in the required field, and selective research according to the designed sample size. These criteria have been classified into three main clusters, economic aspects cluster, social aspects cluster, and environmental aspects cluster. Statistical analysis has been conducted on the interviews feedback. The research aims to trade-off in guiding the decision-maker to direct very limited budgets in the quality of restoration and rehabilitation the efficiency of low-cost or economic housing projects sustainably based on cost factors of projects.
\end{abstract}

Keywords: Rehabilitation; project ranking; Budget allocation; Topsis; Gathered criteria; Hungarian method, the assignment problem.

\section{Introduction}

Low income residential rehabilitation projects have major effects on implementing the principles of sustainable development. The entire life cycle of a building includes construction, operation, maintenance, demolition and removal and the normal expected life span of a building may up to 50 years. Limited budget in concrete rehabilitation in developing countries represents challenges for the decision makers. Reviewing the literature in this field revealed the past attempts to define the criteria and key indicators to be used in allocating the budget in the aforementioned projects. Researches in the area of sustainable urban infrastructure reflect the need to design and manage engineering systems in light of both environmental and socioeconomic considerations. A study developed a framework for the sustainability assessment of urban infrastructure systems [1]. The framework focuses on key indicators and criteria selected to be used in the assessment of urban infrastructure systems. Another study introduced to provide appropriate methods to assess the sustainable development [2]. The study provided a simulation model, using system dynamics principle, to evaluate the sustainability performance of highway infrastructure projects during the construction and operation stage. The study introduced the indicators which measure the sustainability performance of highway projects and identifies the dynamic criteria affecting project performance. [3] Introduced a study which provided key assessment indicators for assessing the sustainability performance of an infrastructure project. The list of the assessment indicators included, economical aspects indicators, social aspects indicators, and environmental aspects indicators. The economic aspects indicators include analysis of market supply and demand, technical advantages, project budget, payback period, and internal return ratio (IRR). The social aspects include effects on local development, public safety, and public sanitation. The environmental aspects include, 


\section{Ahmed Nouh Meshref and M. A. Elsisy" Comparison between Systematical Budget Allocation Modeling Selection Methods in Low-Income Residential Rehabilitation Projects"}

effect on air quality, effect on water quality, and noise effect. Budget is a fiscal plan. Distribution of limited budget in construction projects represents challenges for the decision makers. [4] Provided an empirical study of the budget allocation in transportation projects. The study provided a model to allocate budgets of the transportation projects. The model is limited to constructions projects that have completed feasibility evaluations and the model cannot be used for different allocations for projects with different resources demands. [5] Presented a budget allocation methodology for water mains rehabilitation projects. The methodology aims in the case of limited budget. The methodology consists of two models; the first model classifies the project in five levels according to their level of importance. The second model ranks the projects at the same level to allocate the left budget. [6] Mentioned that the traditional maintenance strategies are not adequate but sustainable approach is the right direction. Along the line, the key criteria affecting sustainable refurbishment are economic considerations, and the obvious benefits relates to social matters. [7] Mentioned that, in order to implement building maintenance tasks efficiently, a proper building maintenance plan and monitoring system is necessary. Financial is often being the barrier to maintenance management in organizing maintenance activities of a building. [8] Presented a study of maintenance management in safety and health practice based on financial criteria. [9] Mentioned that the Sustainability is important expression nowadays to duplicate the natural resources and the wealth of nations. The main objective of this research was to develop a sustainable model aims in allocating the limited budget in concrete rehabilitation projects. As a result, the sustainable development of concrete rehabilitation projects is enhanced.

An analysis of prior studies in the field of rehabilitations projects was performed. A list of 20 criteria has been collected from a comprehensive literature. Structured and Unstructured interviews with senior expert engineers working in the field have been taken place. The main purpose of the unstructured interviews was to review the gathered criteria from the literature. 16 structured interviews have been conducted to collect data relative to the criteria weighting. Statistical analysis has been conducted on the collected data. The normalized relative weight of each criterion has been calculated. The proposed models are developed by using average methods; standard deviation method; and Simo's ranking method. The models rank the projects in descending order according to their total score value. This paper presents the criteria identification and the
Simo's Procedure in section two. Projects case studies have been presented to illustrate the procedures of the proposed model, Topsis method is illustrated in section four.

\section{Criteria Identification}

A preliminary list of 20 criteria has been gathered from literature [1],[2-11],[13],[15-17],[2122] and experts in the same field. Table 1 contains the list of the final 13 criteria. The criteria have been divided into three main clusters: economic criteria, social criteria, environmental criteria. Economic criteria include criteria related to the economic aspects: project capital cost criteria, project operational and maintenance costs (O\&M), payback period criteria, and internal return ratio (IRR) criteria. Social criteria include criteria related to social aspects: effect on other nearest properties, effect on traffic criteria, effect on public health criteria, and effect on the nearest utilities. Environmental criteria include criteria related to environmental aspects: effect on public safety criteria, effect on air quality criteria, effect on water quality criteria, noise effect criteria, and energy saving criteria. The list was reviewed by 16 senior engineers their experience in the same field. The criteria were classified according to sustainable development aspects. Project capital cost criteria was defined as the project with lower capital cost is preferred. Project operational and maintenance costs (O\&M) criteria were defined as the project with lower operational and maintenance costs are preferred. The payback period criteria were defined as the faster payback period is preferred. The internal return ratio (IRR) criteria were defined as the higher ratio is preferred. The effect on other nearest properties criteria was defined as the lower effect on other properties is preferred. The effect on traffic criteria was defined as the lower disruption effect on traffic is preferred. The effect on public health criteria was defined as the lower negative effect on public health is preferred. The effect on the nearest utilities criteria was defined as the lower damage effect on other utilities is preferred. The effect on public safety criteria was defined as the lower negative effect on public safety is preferred. The effect on air quality criteria was defined as the lower negative effect on air quality is preferred. The effect on water quality criteria was defines as the lower negative effect on water quality is preferred. The noise effect criteria were defined as the lower noise effect is preferred. The energy saving criteria was defined as the higher energy saving is preferred. Structured and unstructured interviews with experts' engineers have been taken place to classify and define the final list of criteria. 
Table 1- Final list of Criteria

\begin{tabular}{|c|c|c|}
\hline Cluster & Criteria & Definitions \\
\hline \multirow{4}{*}{$\begin{array}{l}\text { Economic } \\
\text { criteria }\end{array}$} & $\begin{array}{l}\text { 1) Project } \\
\text { Capital cost }\end{array}$ & $\begin{array}{l}\text { The project with } \\
\text { lower capital cost is } \\
\text { preferred }\end{array}$ \\
\hline & $\begin{array}{l}\text { 2)Project } \\
\text { operational and } \\
\text { maintenance } \\
\text { costs }(\mathrm{O} \& \mathrm{M})\end{array}$ & $\begin{array}{l}\text { The project with } \\
\text { lower operational and } \\
\text { maintenance cost is } \\
\text { preferred. }\end{array}$ \\
\hline & $\begin{array}{l}\text { 3) Payback } \\
\text { period, }\end{array}$ & $\begin{array}{l}\text { The faster bay back } \\
\text { period is preferred }\end{array}$ \\
\hline & $\begin{array}{l}\text { 4) internal return } \\
\text { ratio(IRR) }\end{array}$ & $\begin{array}{l}\text { The higher ratio is } \\
\text { preferred }\end{array}$ \\
\hline \multirow{2}{*}{ Social criteria } & $\begin{array}{l}\text { 5) Effect on } \\
\text { other nearest } \\
\text { properties. }\end{array}$ & $\begin{array}{l}\text { The lower effect on } \\
\text { other properties is } \\
\text { preferred. }\end{array}$ \\
\hline & $\begin{array}{l}\text { 6) Effect on } \\
\text { traffic, }\end{array}$ & $\begin{array}{l}\text { The lower disruption } \\
\text { effect on traffic is } \\
\text { preferred. }\end{array}$ \\
\hline
\end{tabular}

Structured interviews with experts have been conducted to collect the required data belong to the criteria 'relative weights. Each expert was asked to rank the criteria of each cluster in ascending order. They, also, asked to rank the main cluster in the same manner. R1, R2, R3, R4, R5, and R6 till R16, are the responds of the 16 experts. The average value has been calculated for each criteria and each cluster. The criteria in each cluster have ranked according to their average values. The main clusters also, were ranked in the same manner. Table 2 contains the expert's responds and the calculation of the average value and the ranking of the criteria and the clusters. The normalized weights of the criteria were calculated. For example, the normalized weight for the project capital cost criteria $=4 /(1+2+3+4)=4 / 10=0.4$. The calculation of the normalized relative weights of the remaining criteria will be calculated in the same manner. The normalized relative weight for each cluster was calculated [23]. The global criteria's weight was calculated by multiplying the criteria's normalized relative weight by its cluster normalized weight. For example, the project capital cost criteria's global weight $=$ the economic cluster normalized weight $*$ the project capital cost normalized weight. The project capital cost criteria's global weight $=$ $1 / 3 *(0.4)=0.133$. The global weight for the other criteria has been calculated by the same way. Table 3 contains the calculated normalized and global criteria's weights. Criteria that have weights $\geq 0.10$ are: Project Capital cost, Project operational and maintenance costs (O\&M), Effect on other nearest properties, Effect on traffic, and Effect on public health. The remaining criteria have weights $<0.10$.

\begin{tabular}{|c|c|c|}
\hline & $\begin{array}{l}\text { 7) Effect on } \\
\text { public health }\end{array}$ & $\begin{array}{l}\text { The lower negative } \\
\text { effect on public } \\
\text { health is preferred. }\end{array}$ \\
\hline & $\begin{array}{l}\text { 8) Effect on the } \\
\text { nearest utilities. }\end{array}$ & $\begin{array}{l}\text { The lower damage } \\
\text { effect on other } \\
\text { utilities is preferred. }\end{array}$ \\
\hline \multirow{5}{*}{$\begin{array}{l}\text { Environmental } \\
\text { criteria }\end{array}$} & $\begin{array}{l}\text { 9) Effect on } \\
\text { public safety }\end{array}$ & $\begin{array}{l}\text { The lower negative } \\
\text { effect on public } \\
\text { safety is preferred. }\end{array}$ \\
\hline & $\begin{array}{l}\text { 10) Effect on air } \\
\text { quality }\end{array}$ & $\begin{array}{l}\text { The lower negative } \\
\text { effect on air quality is } \\
\text { preferred. }\end{array}$ \\
\hline & $\begin{array}{l}\text { 11) Effect on } \\
\text { water quality }\end{array}$ & $\begin{array}{l}\text { The lower negative } \\
\text { effect on water } \\
\text { quality is preferred. }\end{array}$ \\
\hline & 12) Noise effect & $\begin{array}{l}\text { The lower noise } \\
\text { effect is preferred. }\end{array}$ \\
\hline & $\begin{array}{ll}\text { 13) } & \text { Energy } \\
\text { saving } & \end{array}$ & $\begin{array}{l}\text { The higher energy } \\
\text { saving is preferred. }\end{array}$ \\
\hline
\end{tabular}

The effect on traffic criteria has the higher weight. The noise effect criteria have the lower weight. The economic aspect criteria have a total weight equal (0.333). The social aspect criteria have a total weight equal (0.5). The environmental aspects criteria have a total weight equal (0.17).

Table 2- Simo's Interview's Feedback

\begin{tabular}{|c|c|c|c|}
\hline Clusters & Criteria & Average & Rank \\
\hline \multirow{4}{*}{$\begin{array}{l}\text { Economic } \\
\text { criteria }\end{array}$} & 1) Project Capital cost & 3.7 & 4 \\
\hline & 2) Project $(O \& M)$ costs & 2.7 & 3 \\
\hline & 3) Payback period & 1.5 & 1 \\
\hline & $\begin{array}{l}\text { 4) internal return ratio } \\
\text { (IRR) }\end{array}$ & 2.3 & 2 \\
\hline \multirow{4}{*}{ Social criteria } & $\begin{array}{l}\text { 1) Effect on other } \\
\text { nearest properties. }\end{array}$ & 2.7 & 2 \\
\hline & 2) Effect on traffic & 3.5 & 4 \\
\hline & $\begin{array}{l}\text { 3) Effect on public } \\
\text { health }\end{array}$ & 2.8 & 3 \\
\hline & $\begin{array}{l}\text { 4) Effect on the nearest } \\
\text { utilities. }\end{array}$ & 2 & 1 \\
\hline \multirow{5}{*}{$\begin{array}{c}\text { Environmental } \\
\text { criteria }\end{array}$} & $\begin{array}{l}\text { 1) Effect on public } \\
\text { safety }\end{array}$ & 3.8 & 5 \\
\hline & 2) Effect on air quality & 3.5 & 4 \\
\hline & $\begin{array}{l}\text { 3) Effect on water } \\
\text { quality }\end{array}$ & 3.2 & 3 \\
\hline & 4) Noise effect & 1.8 & 1 \\
\hline & 5) Energy saving & 2.2 & 2 \\
\hline \multirow{3}{*}{ Main clusters } & Economic & 2.5 & 2 \\
\hline & Social & 2.2 & 3 \\
\hline & Environmental & 1.8 & 1 \\
\hline
\end{tabular}


Table 3- Normalized and Global weights

\begin{tabular}{|c|c|c|c|}
\hline & Criteria & $\begin{array}{c}\text { Normalized } \\
\text { weight }\end{array}$ & $\begin{array}{l}\text { global } \\
\text { weight }\end{array}$ \\
\hline \multirow[t]{4}{*}{$\begin{array}{l}\text { Economic } \\
\text { criteria }\end{array}$} & $\begin{array}{l}\text { 1- Project } \\
\text { Capital cost }\end{array}$ & $4 / 10=0.4$ & $\begin{array}{l}0.4 / 3= \\
0.133\end{array}$ \\
\hline & $\begin{array}{l}\text { 2- Project } \\
\text { operational } \\
\text { and } \\
\text { maintenance } \\
\text { costs(O\&M) }\end{array}$ & $3 / 10=0.3$ & $\begin{array}{l}0.3 / 3= \\
0.10\end{array}$ \\
\hline & $\begin{array}{l}\text { 3- Payback } \\
\text { period }\end{array}$ & $1 / 10=0.1$ & $\begin{array}{l}0.1 / 3= \\
0.033\end{array}$ \\
\hline & $\begin{array}{l}\text { 4- internal } \\
\text { return ratio } \\
\text { (IRR) }\end{array}$ & $2 / 10=0.2$ & $\begin{array}{l}0.2 / 3= \\
0.067\end{array}$ \\
\hline \multirow[t]{4}{*}{ Social criteria } & $\begin{array}{l}5 \text { - Effect on } \\
\text { other nearest } \\
\text { properties }\end{array}$ & $2 / 10=0.20$ & $\begin{array}{l}0.2 / 2= \\
0.10\end{array}$ \\
\hline & $\begin{array}{l}\text { 6- Effect on } \\
\text { traffic }\end{array}$ & $4 / 10=0.40$ & $\begin{array}{l}0.4 / 2= \\
0.2\end{array}$ \\
\hline & $\begin{array}{l}\text { 7- Effect on } \\
\text { public } \\
\text { health }\end{array}$ & $3 / 10=0.30$ & $\begin{array}{l}0.3 / 2= \\
0.15\end{array}$ \\
\hline & $\begin{array}{l}\text { 8- Effect on } \\
\text { other nearest } \\
\text { utilities }\end{array}$ & $1 / 10=0.10$ & $\begin{array}{l}0.1 / 2= \\
0.05\end{array}$ \\
\hline \multirow[t]{5}{*}{$\begin{array}{c}\text { Environmental } \\
\text { criteria }\end{array}$} & $\begin{array}{l}\text { 9- Effect on } \\
\text { public safety }\end{array}$ & $5 / 15=0.33$ & $\begin{array}{l}0.33 / 6= \\
0.06\end{array}$ \\
\hline & $\begin{array}{l}\text { 10- Effect } \\
\text { on air } \\
\text { quality }\end{array}$ & $4 / 15=0.27$ & $\begin{array}{l}0.27 / 6= \\
0.05\end{array}$ \\
\hline & $\begin{array}{l}11 \text { - Effect } \\
\text { on water } \\
\text { quality }\end{array}$ & $3 / 15=0.2$ & $\begin{array}{l}0.2 / 6= \\
0.03\end{array}$ \\
\hline & $\begin{array}{l}\text { 12- Noise } \\
\text { effect }\end{array}$ & $1 / 15=0.07$ & $\begin{array}{l}0.07 / 6= \\
0.01\end{array}$ \\
\hline & $\begin{array}{l}\text { 13- Energy } \\
\text { saving }\end{array}$ & $2 / 15=0.13$ & $\begin{array}{l}0.13 / 6= \\
0.02\end{array}$ \\
\hline
\end{tabular}

The proposed model is developed by using the scoring weighted criteria model. The proposed model was applied before implementing the projects. The proposed model is generated mathematically using Equation (1). The total score of the project equals the summation of the criteria's adjustment value. The criteria's adjustment value equals the multiplication of the criteria's weight by the criteria's score value $\left(W_{j} * S_{i}\right)$ [23-26]. The criteria's score value is the normalized average value given by number of experts. Projects were ranked in descending order according to their total scores. The budget was distributed first for the projects with high total scores.

$$
\text { Project's total score }=\sum W_{j} * S_{i}(1)
$$

where $W_{j}$ is the criteria's relative weight, $S_{i}$ is the criteria's score from one to three.

The experts should give scores for each criterion for the first project. The average scoring value is calculated for each criterion. The adjustment value for each criterion is calculated by multiplying the scoring value by the criteria's weight. The total score of the project is calculated by summing the adjustment values of all the 13 criteria. The total score of the second project is calculated as the same way and so on. The projects are ranked in descending order according their total scores. The budget is allocated first to the project with the higher total score. The remaining budget is allocated to the rest projects according to their total scores value. If the remain budget is insufficient, the remaining projects will be left to the next fiscal year.

\section{Topsis method}

It is assumed that there are three rehabilitation projects: $P_{1}, P_{2}$ and $P_{3}$. The total budgets for the three projects were one million L.E, two million L.E and three million L.E, respectively. The total available budget is five million L.E. It is required to allocate the budget for the three projects. The following section explains the procedures of applying the proposed models. Table 4 contains the calculation of the total score of the first project. We have three experts to give scores for the criteria of each project. The experts gave scores for the project criteria in columns from R1 to R3.

By using the Simo's Procedure to select the ranking of project first, the average value is calculated for each criterion [23-24-26]. The adjustment value for each criterion is calculated. The adjustment value is calculated by multiplying the criteria's score by its weight as shown in Table 4 . The total score of the project is calculated by the summation of the last column in the table. The total scores calculations of projects $P_{2}$ and $P_{3}$ were 3.5 and 3.2 respectively. The budget will be distributed for the first project with 3.8 total score and $P_{2}$ with total score 3.4. The remaining budget will be 2 million. The remaining budget is not enough for project $P_{3}$. The project $P_{3}$ will be left for the next fiscal year. 
Table 4- The expert's scores for each project criteria

\begin{tabular}{|c|c|c|c|c|c|c|c|c|c|c|}
\hline \multirow[b]{2}{*}{ Clusters } & \multirow[b]{2}{*}{ Factors } & \multicolumn{3}{|c|}{ Project 1} & \multicolumn{3}{|c|}{ Project 2} & \multicolumn{3}{|c|}{ Project 3} \\
\hline & & R1 & $\mathbf{R 2}$ & $\mathbf{R 3}$ & R1 & $\mathbf{R 2}$ & $\mathbf{R 3}$ & $\mathbf{R 1}$ & $\mathbf{R 2}$ & $\mathbf{R 3}$ \\
\hline \multirow{4}{*}{ Economic } & 1- Project Capital cost & 4 & 5 & 4 & 5 & 5 & 5 & 3 & 4 & 4 \\
\hline & $\begin{array}{l}\text { 2- Project operational and maintenance } \\
\text { costs }(O \& M)\end{array}$ & 3 & 3 & 2 & 4 & 4 & 4 & 4 & 4 & 5 \\
\hline & 3- Payback period & 3 & 2 & 1 & 4 & 4 & 3 & 3 & 5 & 4 \\
\hline & 4- internal return ratio (IRR) & 4 & 3 & 1 & 4 & 4 & 3 & 5 & 4 & 4 \\
\hline \multirow{4}{*}{ Social } & 5- Effect on other nearest properties & 5 & 4 & 3 & 2 & 3 & 3 & 2 & 2 & 3 \\
\hline & 6- Effect on traffic & 4 & 5 & 5 & 3 & 4 & 4 & 3 & 3 & 3 \\
\hline & 7- Effect on public health & 5 & 3 & 4 & 4 & 5 & 5 & 5 & 5 & 4 \\
\hline & 8- Effect on other nearest utilities & 5 & 3 & 5 & 3 & 4 & 4 & 4 & 2 & 2 \\
\hline \multirow{5}{*}{ Environmental } & 9- Effect on public safety & 4 & 5 & 5 & 3 & 4 & 4 & 2 & 5 & 5 \\
\hline & 10- Effect on air quality & 3 & 3 & 4 & 3 & 4 & 3 & 4 & 4 & 3 \\
\hline & 11- Effect on water quality & 4 & 3 & 3 & 2 & 2 & 4 & 3 & 1 & 2 \\
\hline & 12- Noise effect & 5 & 2 & 1 & 4 & 4 & 4 & 3 & 5 & 5 \\
\hline & 13- Energy saving & 5 & 3 & 3 & 4 & 5 & 5 & 5 & 4 & 5 \\
\hline & Project cost & \multicolumn{3}{|c|}{ 1million L.E } & \multicolumn{3}{|c|}{ 2million L.E } & \multicolumn{3}{|c|}{ 3million L.E } \\
\hline
\end{tabular}


Table 5- Calculation of the first project.

\begin{tabular}{|c|c|c|c|c|}
\hline Clusters & Criteria & Criteria's weight & Average & Adjustment value \\
\hline \multirow[t]{4}{*}{ Economic } & 1- Project Capital cost & 0.133 & 4.5 & 0.6 \\
\hline & $\begin{array}{l}\text { 2- Project operational and } \\
\text { maintenance } \\
\text { costs }(\mathrm{O} \& \mathrm{M})\end{array}$ & 0.10 & 2.5 & 0.25 \\
\hline & 3- Payback period & 0.033 & 1.5 & 0.05 \\
\hline & $\begin{array}{ll}4- & \text { internal return ratio } \\
\text { (IRR) }\end{array}$ & 0.067 & 2 & 0.134 \\
\hline \multirow[t]{4}{*}{ Social } & $\begin{array}{l}\text { 5- Effect on other nearest } \\
\text { properties }\end{array}$ & 0.10 & 3.5 & 0.35 \\
\hline & 6- Effect on traffic & 0.2 & 5 & 1 \\
\hline & 7- Effect on public health & 0.15 & 3.7 & 0.6 \\
\hline & $\begin{array}{l}\text { 8- Effect on other nearest } \\
\text { utilities }\end{array}$ & 0.05 & 4 & 0.2 \\
\hline \multirow[t]{5}{*}{ Environmental } & 9- Effect on public safety & 0.06 & 5 & 0.3 \\
\hline & 10- Effect on air quality & 0.05 & 3.7 & 0.185 \\
\hline & 11-Effect on water quality & 0.03 & 3 & 0.09 \\
\hline & 12- Noise effect & 0.01 & 1.5 & 0.015 \\
\hline & 13- Energy saving & 0.02 & 3 & 0.06 \\
\hline
\end{tabular}

Table 6- Simo's budget allocation values

\begin{tabular}{lcc}
\hline & Index & Rank \\
\hline Project 1 & 3.8 & 1 \\
Project 2 & 3.5 & 2 \\
Project 3 & 3.2 & 3 \\
\hline
\end{tabular}

By Using Topsis Method:

The average of: $x_{1}, x_{2}, \ldots, x_{n}$ equals

$$
\bar{x}=\sum_{i=1}^{n} x_{i} / n \cdot(2)
$$

The standard deviation:

$$
\delta=\sqrt{\frac{1}{n} \sum_{i=1}^{n}\left(x_{i}-\bar{x}\right)} .
$$

We find the average/ standard derivation of R1, R2 and R3 for each criterion. The average/ standard derivation of each criteria of economic cluster is summed to be one number $x_{i j}$. [12],[14],[20] Also, we do that for social and environmental clusters. The associated weights $w_{j}$ are calculated by sum the economic cluster of all projects. Also, we do that again for social and environmental clusters. We have three numbers for economic, social and environmental clusters. Add the available cost and normalized these four numbers.

- Topsis method consists of the following steps:
1. We find the average of R1, R2 and R3 for each criterion.

2. The average of each criteria of each cluster is summed to be one number $x_{i j}$.

3. Add the cost of each project.

4. Reformatted the matrix as $=\left[x_{i j}\right]_{4 \times 3}$. (4)

5. Calculate the associated weights $w_{j}$ by sum each cluster and cost of all projects.

6. Normalize the matrix:

$$
r_{i j}=\frac{x_{i j}}{\sqrt{\sum_{k=1}^{4} x_{k j}^{2}}} i=1, \ldots, 4 ; j=1, \ldots, 3 \text {. }
$$

7. Multiply the columns of normalized decision matrix by the associated weights:

$$
v_{i j}=w_{j} \times r_{i j}, \quad i=1,2,3,4 ; j=1,2,3 \quad \text { (6) }
$$

8. Determine the positive ideal and negative ideal solutions, respectively, as follows:

$$
A^{+}=\left\{v_{1}^{+}, v_{2}^{+}, v_{3}^{+}\right\}, A^{-}=\left\{v_{1}^{-}, v_{2}^{-}, v_{3}^{-}\right\} \text {(8) }
$$

9. Obtain the distances of the existing alternatives from the positive ideal and negative ideal solutions: two Euclidean distances for each alternative are, respectively, calculated as follows:

$$
\begin{gathered}
S_{i}^{+}=\sqrt{\sum_{j=1}^{3}\left(v_{i j}-v_{j}^{+}\right)^{2}}, i=1,2,3,4 . \\
S_{i}^{-}=\sqrt{\sum_{j=1}^{3}\left(v_{i j}-v_{j}^{-}\right)^{2}}, i=1,2,3,4
\end{gathered}
$$




\section{Ahmed Nouh Meshref and M. A. Elsisy" Comparison between Systematical Budget Allocation Modeling Selection Methods in Low-Income Residential Rehabilitation Projects"}

10. Calculate the relative closeness to the ideal alternatives:

$$
R C_{i}=\frac{S_{i}^{-}}{S_{i}^{+}+S_{i}^{-}} \cdot(10)
$$

11. By ranking the alternatives according to the relative closeness to the ideal alternatives then the bigger is the $R C_{i}$, the better is the alternative $A_{i}$

Table 7- Results of using average as measure

\begin{tabular}{lccc}
\hline & Economic & Social & Environmental \\
\hline Project 1 & 0.06 & 0.03 & 0.36 \\
Project3 & 0.03 & 0.06 & 0.64 \\
Project 2 & 0.027 & 0.06 & 0.69 \\
\hline
\end{tabular}

Table 8- Results of using standard derivation as measure

\begin{tabular}{lccc}
\hline & $\begin{array}{c}\text { Economi } \\
\text { c }\end{array}$ & Social & Environmental \\
\hline Project 2 & 0.34 & 0.06 & 0.14 \\
Project 1 & 0.12 & 0.28 & 0.70 \\
Project 3 & 0.11 & 0.29 & 0.72 \\
\hline
\end{tabular}

If the DM desired to choose on economic or social or environmental, we solve the problem as the assignment problem. Assignment problem [18] is used in solving many of engineering problems and management science problems. The assignment problem is a special type of linear programming problem (LPP) in which our objective is to assign $n$ number of jobs to $m$ number of machines (persons) at a minimum cost. To find solution to assignment problems, various algorithm such as linear programming and Hungarian algorithm [19] have been developed.

Hungarian method used to solve the assignment problem. It chooses the best choice depending on its criteria. When we use it to solve our problem, the project 1 is the best one depending on the social view. The project 2 on the economic view and the best one in the environmental is project 3 .

Table 9- Results of assignment problem method (Hungarian algorithm) [19]

\begin{tabular}{llll}
\hline & Economic & Social & Environmental \\
\hline Project 1 & 11.67 & 17 & 17.67 \\
Project 2 & 16.33 & 14.67 & 18.33 \\
Project 3 & 16.33 & 12.67 & 18.67 \\
\hline
\end{tabular}

Table 10- Total results of project ranking

\begin{tabular}{llll}
\hline Simo's & $\begin{array}{c}\text { Topsis } \\
\text { (average as } \\
\text { measure) }\end{array}$ & $\begin{array}{c}\text { Topsis } \\
\text { (standard } \\
\text { derivation } \\
\text { as measure) }\end{array}$ & $\begin{array}{c}\text { Assignment } \\
\text { problem }\end{array}$ \\
\hline Project 1 & Project 1 & Project 2 & Project 2 \\
Project 2 & Project3 & Project 1 & Project 1 \\
Project 3 & Project 2 & Project 3 & Project 3 \\
\hline
\end{tabular}

As mentioned before we employed an optimized comparison analysis proposed a comprehensive various decision-making tools which are Assignment method, Topsis method and simo's ranking method. The output values of average and standard deviation methods are used in Topsis method. This proposed comparative study aims the DM decision maker to select the optimum method in allocating the very limited budget in Low income residential rehabilitation projects according to the associated criteria condition of any new project, "DM" decision makers analysis based on the associated conditions of any project classified into three main clusters, economic aspects cluster, social aspects cluster, and environmental aspects cluster. This paper presented three different models for the low income residential rehabilitation projects in Egypt. The proposed models aims in allocating the limited budget assigned for specific projects. There are a list of twenty criteria have been gathered and filtered from the literature and filtered by the experts. These final criteria list have been used in developing the proposed models. The proposed models can be generated suing the Excel program. As presented in table 10, we concluded that project ranking decisions, ranked in descending order according to the applied method and the project associated criteria condition. The average method ranks the projects as the following: project 3 is ranked in the first level, project 2 is ranked in the second level, and both project 1 is ranked in level 3, The standard deviation method ranks the projects as the same as the average method, Simo's method ranks the projects according to the following: Project 1 is ranked in the first level, project 2 is ranked in the second level, project 3 is ranked in the third level. 


\section{Ahmed Nouh Meshref and M. A. Elsisy" Comparison between Systematical Budget Allocation Modeling Selection Methods in Low-Income Residential Rehabilitation Projects"}

\section{Conclusions}

This paper provided two models to allocate budgets of rehabilitation projects in low income residential projects. This paper proposed a comprehensive comparison between Topsis method and simo's ranking method. Also, the assignment problem method presented to select the suitable and optimum project according to the variable conditions of each project depending on the importance and priority for clusters. The paper aims to trade-off in guiding the decision-maker to direct very limited budgets in the quality of restoration and upgrading the efficiency of low-cost or economic housing projects sustainably based on the cost factors of projects.

The models are limited to constructions projects that have completed feasibility evaluations and the model can be used for different allocations for projects with limited resources demands. The three methods can be used in the analysis of construction project decision making. The proposed models methods are very simple to use which can be used with Excel program and matlab software applications. The average method and the standard deviation method depend on the simple traditional arithmetic methods, but simos method depends on the statistical analysis of the collected data. The budget allocation methods proposed in this paper can be easily meet the actual changing demands of response budget policies. When budgets need to be reduced or increased, we can quickly decide in which units and of which projects of each particular budget should be reduced or increased. The proposed budget allocation models presented in this paper can simultaneously distribute the budget of the required projects of a limited budget and also the construction budgets for each unit.

\section{References}

[1] Sahely, H., Kennedy, C; Adams, B., Developing Sustainability Criteria for Urban Infrastructure Systems, Canadian Journal of Civil Engineering, 2005; 32 (1), 72-85.

[2] Hong, Y., Liyin, S., Yongtao, T., Jianli, H., Simulating the impacts of Policy Scenarios on Sustainability performance of infrastructure projects, 2011; 20, 1060-1069.

[3] Shen, L., wu, Y., Zhang, X., Key Assessment Indicators for the Sustainability of Infrastructure Projects, Journal of construction engineering and management, 2011; 6(137), 451-441.

[4] Huang, W., Teng,J., Lin, M., The budget allocation model of public infrastructure projects, 2010; 18(5), 708 - 697.
[5] Marzouk, M., Hamid, S., Budget Allocation water mains Rehabilitation projects using Simos' Procedure, HBRC Journal, 2015; , 1-7.

[6] Chan, E., Building Maintenance Strategy: A Sustainable Refurbishment Perspective, Universal Journal of Management, 2014; 2(1), 25-19.

[7] Ali, A., Kamaruzzaman, S., Sulaiman, R., Peng, Y., Practice Briefing Criteria affecting housing maintenance cost in Malaysia, Journal of Facilities Management, 2010; 8(4), 285-298.

[8] Zakaria, H., Arifin, K., Ahmad, S., Aiyub, K., Financial Criteria Affecting Maintenance Management In Safety And Health Practices, International Journal of Modern Engineering Research, 2012; 2(5), 3067-3061.

[9] Marzouk, Mohamed., Nouh Meshref, Ahmed., El-Said, Moheeb., Developing green bridge rating system using Simo's procedure, January 2013; DOI:10.1016/j.hbrcj.2013.10.001

[10] Sameh, A., Mohamadien, M., Eisawy, A., Arabi, I., Sustainability criteria affecting maintenance of residential buildings, International journal of management 2015; 3(11), 30-15.

[11] Said Abdel Hamid., Nouh Meshref, Ahmed., Zabel, Nael Y., A model for prioritizing concrete structures repair works; May 2017 , DOI: 10.1016/j.hbrcj.2017.04.001

[12] Tavana, M., Keramatpour, M., Santos-Arteaga, F. J., Ghorbaniane, E. (2015). A fuzzy hybrid project portfolio selection method using data envelopment analysis, TOPSIS and integer programming. Expert Systems with Applications, 42(22), 8432-8444.

Doi: 10.1016/j.eswa.2015.06.057.

[13] Ngacho, C., Das, D. (2014). A performance evaluation framework of development projects: An empirical study of Constituency Development Fund (CDF) construction projects in Kenya. International Journal of Project Management, 32(3), 492-507.

Doi: 10.1016/j.ijproman.2013.07.005.

[14] Lee, K. L., Huang, W. C., and Teng, J. Y., "Locating the competitive relation of global logistics hub using quantitative SWOT analytical method," Quality and Quantity, 
http://www.springerlink.com, published online: 29 March (2007).

[15] Mahdi, I. M., Riley, M. J., Fereig, S. M., and Alex, A. P., "A multi-criteria approach to contractor selection," Engineering Construction and Architectural Management, Vol. 9, No. 1, pp. 29-37 (2002).

[16] McIntyre, C. and Parfitt, M. K., "Decision support system for residential land development site selection process," Journal of Architectural Engineering, ASCE, Vol. 4, No. 4, pp. 125-131 (1998).

[17] Kim, S. Y., \& Huynh, T. A. (2008). Improving project management performance of large contractors using benchmarking approach. International Journal of Project Management, 26(7), 758-769.

Doi: $10.1016 /$ j.ijproman.2007.10.002

[18] Pentico DW. Assignment problems: A golden anniversary survey. European Journal of Operational Research. 2007 Jan 16;176(2):77493.

[19] Kumar PS, Hussain RJ. A method for finding an optimal solution of an assignment problem under mixed intuitionistic fuzzy environment. In Proceedings in international conference on mathematical sciences (ICMS-2014) Elsevier, Chennai 2014 (pp. 417-421).

[20] Zadeh, L.A. (1965). "Fuzzy sets". Information and Control, Vol. 8, No.3, 338-353.

[21] Zhao, J., \& Rajani, B. (2002). Construction and Rehabilitation Costs for Buried Pipe with a Focus on Trenchless Technologies. Institute for Research in Construction, National Research Council Canada. Ottawa, Ontario, Canada.
[22] Atef, A., Osman, H., \& Moselhi, O. (2011). Budget allocation for water and sewer infrastructure. Annual meeting of Canadian Society of civil Engineers, Canadian Society of Civil Engineers, Ottawa, Canada

[23] Nouh Meshref, A., E.A, Elkasaby., Wageh, O., (2020) Innovative reliable approach for optimal selection for construction infrastructures projects delivery systems, Innovative Infrastructure Solutions Journal: Springer Nature Switzerland, Volume 5, Issue 2, August 2020 : https://doi.org/10.1007/s41062-02000307-w

[24] Meshref, A.N., Shehata, A.S. Exploring the criteria influencing construction productivity of diaphragm walls in underground stations in Egypt. Innov. Infrastruct. Solut. 5, 105 (2020). https://doi.org/10.1007/s41062-020-00353-4

[25] Nouh Meshref, A., S. Shehata, A. Systematic decision support system to select methods of grouted base plug construction: comparative study between $\mathrm{TaM}$ versus multi-sleeve injection. Innov. Infrastruct. Solut. 5, 67 (2020). https://doi.org/10.1007/s41062-020-00319-6

[26] Meshref, A.N., Elkasaby, E.A. \& Wageh, O. Identifying Innovative Reliable Criteria Governing the Selection of Infrastructures Construction Project Delivery Systems. Open Engineering. January 16, 2021. Volume 11 Issue 1. De Gruyter.

DOI: https://doi.org/10.1515/eng-2021-0028 